Copyright (C) 2021 by Cherkas Global University

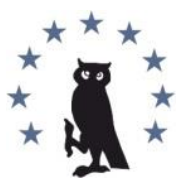

Published in the USA

Russkaya Starina

Has been issued since 2010.

E-ISSN: $2409-2118$

2021. 12(2): 112-118

DOI: $10.13187 /$ rs.2021.2.112

https://rs.cherkasgu.press

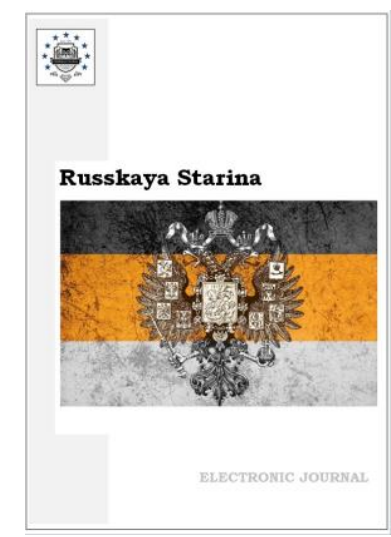

\title{
The Press of the Donbass in 1941-1943
}

Tatyana Yu. Lyudorovskaya ${ }^{a}$,

${ }^{a}$ Donetsk National University

\begin{abstract}
The article analyzes the printed mass media that were published on the territory of the Donbass during the occupation period (1941-1943). The main newspapers of the region were "Socialist Donbass", "Donetsk Bulletin", "Grain Grower", "Bakhmut Bulletin", "Donbass Rebuff". They continued their work during the occupation regime, often becoming underground. Since September 1941, the structure of the print media in the Donbass has been reorganized, when new newspapers began to appear along with the existing ones. A comparison of the materials of local newspapers makes it possible to determine the main focus and the degree of completeness of the description of events taking place on the territory of the Donbass, to identify the specifics of the functioning of the occupation authorities, as well as to identify distortions and inaccuracies in the provision of information.
\end{abstract}

Keywords: mass media, press, Donbass, Great Patriotic War, occupation regime, newspaper.

\section{1. Введение}

В современных условиях развития общества средства массовой информации превратились в мощный рычаг воздействия на коллективное сознание. Наибольших масштабов достигла эта тенденция в странах, находящихся в состоянии войны. В условиях полного контроля СМИ превратились в один из важнейших инструментов государственной агитации и пропаганды. Максимально использовался этот инструмент и на территории Донбасса как в довоенный период, так и в ходе Великой Отечественной войны. К общему числу источников, раскрывающих вопросы оккупационного режима в регионе в 19411943 гг., можно отнести прессу, которая публиковалась во время оккупации.

Целью исследования является характеристика печатных средств массовой информации, издававшихся на территории Донбасса в 1941-1943 гг.

\section{2. Материалы и методы}

Некоторые аспекты данной проблематики нашли отражение в отечественной историографии. Вопросам использования прессы в качестве исторического источника, методике ее исследования посвящены работы Д.Н. Титаренко (Титаренко, 2002; Титаренко, 2009). Определенный вклад в разработку проблемы функционирования подпольнопартизанской прессы в Украинской ССР в течение немецко-фашистской оккупации был сделан в монографии И.Л. Демьянчука (Дем'янчук, 1956). Случаи использования

\footnotetext{
${ }^{*}$ Corresponding author

E-mail addresses: t.ludorov@mail.ru (T.Yu. Lyudorovskaya)
} 
оккупационных газет в пропагандистских целях подпольщиками и партизанами Восточной Украины приводились в работе И.Я. Омельяненко (Омельяненко, 1972). В то же время требуется более детальный анализ функционирования печатных СМИ на территории Донбасса в оккупационный период.

Первоочередное значение имели периодические издания, выходившие на оккупированной территории Донбасса в 1941-1943 гг., которые хранятся в государственных архивах Донецкой Народной Республики (ГА ДНР) и Луганской Народной Республики (ГА ЛНР). В докладных записках в ЦК КП(б)У органов разведки НКВД, отчетах нацистских пропагандистских органов содержатся ценные сведения о направлениях ведения пропаганды на оккупированной территории прифронтовой полосы, дислокации подразделений пропаганды вермахта, действовавших на территории Донбасса, источниках поступления информации в газеты, издававшиеся в оккупированном регионе.

Согласно данным ГА ЛНР, в каждом городе и районном центре Донбасса выходила газета, которая была органом государственной управы: в г. Юзовка (Донецк) - «Донецкий вестник», в г. Артемовске - «Бахмутский вестник», в г. Волноваха - «Хлебороб», в г. Горловка - «Голос Донбасса», в г. Енакиево - «Новая жизнь», в г. Константиновка «Константиновские вести», в г. Мариуполь - «Мариюпольская газета», в г. Чистяково (Торез) «Новая жизнь» и «Чистяковский листок» (ГА ЛНР. Ф. 46. Оп. 1. Д. 5204. Л. 125).

\section{3. Обсуждение и результаты}

До немецко-фашистской оккупации на территории Донбасса функционировала разветвленная сеть официальных периодических изданий, представленная 24 газетами и 1 журналом, из которых 19 выпускались на территории Сталинской (Донецкой) области, 5 - Ворошиловградской (Луганской). Периодичность выхода пяти газет - от 4 до 7 раз в неделю, восьми - 1 раз в неделю, остальные издания выходили 2-3 раза в неделю. На своих страницах печатные органы помещали значительное количество информации по вопросам местной жизни (Донецкая область, 1982: 165). Особенность анализируемой прессы заключается в том, что ее материалы значительно расширяют возможности исследователей при освещении социально-экономического состояния и духовной жизни Донбасса в 19411943 гг., подпольно-партизанского движения и хода боевых действий советских и немецких войск на территории региона.

В оккупационный период на территории Донбасса произошла кардинальная перестройка структуры прессы, были созданы новые центральные военные газеты: фронтовые, армейские, дивизионные издания. Номера армейских газет - синтез из партийных передовых, сообщений Совинформбюро о положении на фронтах с подробным описанием боевых действий, информации о жизни в тылу, а также краткого освещения международных событий. Зачастую корреспонденты военных газет принимали материал прямо в землянках или окопах, иногда даже на огневых позициях.

Среди основных источников прессы периода оккупации в Донбассе особого внимания заслуживают газеты «За Родину», «“Правда” в Донбассе», «Донбасский отпор», многотиражка «Кировец», в которых освещалась деятельность советских патриотов на захваченных территориях, высмеивалась примитивность нацистской пропаганды, приводились примеры экономической эксплуатации местного населения, а также сообщалось о репрессиях против подпольщиков и партизан.

5 мая 1941 г. в Донецке проводилось торжественное собрание, посвященное Дню советской печати, после которого все его участники - журналисты и рабселькоры направились на площадь им. Дзержинского, где проходило массовое гулянье в честь праздника прессы. Участники собрания спорили о том, как в дальнейшем осуществить все свои творческие замыслы, договаривались о совместных рейдах, рабкоровских смотрах. «Кто мог предполагать в тот праздничный вечер, - вспоминает один из старейших журналистов Донбасса, корреспондент газеты «Правда» Д. Акулышин, - что через полтора месяца грянет война... Когда же озверелые фашистские орды вторглись в пределы нашей страны, редакции донецких газет стали и днем, и ночью напоминать растревоженный улей. Ежедневно уходили на фронт журналисты: одних призывали, другие отправлялись в армию добровольцами. А те, кто оставался, работали за двоих, за троих. И газеты выходили регулярно. Только страницы их изменили свое лицо. Теперь они рассказывали о мужестве 
и героизме советских воинов на фронтах Великой Отечественной войны, о самоотверженном труде работников тыла, ковавших победу над врагом» (ГА ДНР. Ф. 4674. Оп. 1. Д. 7. Л. 13).

В большой трудовой армии донбассовцев еще до начала оккупации была создана газета «Донбасский отпор», в редакцию которой вошли донецкие журналисты Н.М. Протасов, И.И. Зенин, А.И. Ярмаль, Б.М. Щаранский, М.М. Сорокин, а ее активными помощниками стали сотни бывших рабкоров и селькоров.

12 сентября 1941 г. в пятом номере газеты «Донбасский отпор» сообщалось: «В районе тов. Яншина на всех дистанциях организованы редколлегии. Первые боевые листки вышли в свет 7 сентября. В стенновке дистанции № 1 показана многообразная лагерная жизнь. Рабкоры особенно уделяли внимание вопросам производства и агитационно-массовой работе. Передовики-стахановцы поделились опытом организации труда. Такие боевые листки теперь будут выходить на дистанции ежедневно».

На страницах этой прифронтовой газеты для поднятия боевого духа, патриотических настроений периодически сообщалось о рабкоровской инициативе во время войны: «Три раза в день передвигается по дистанции тов. Бережного щит с прибитым к нему стендом. На щите под старательно разрисованным заголовком - стенная газета. Утром газета находится на левом фланге дистанции, днем - в центре, перед вечером передвигается на правый фланг. Газет таких в районе, руководимом товарищем Петровым, имеется пять. Выпускаются они ежедневно редколлегией, находящейся при районном управлении. Каждая из пяти газет имеет свое название и построена на материале, отображающем будни данной дистанции. Помогает газете в этом обширный рабкоровский актив, который она имеет. - Еще в дороге, когда наш эшелон двигался к месту назначения, - рассказывает редактор тов. Бондарев, - я обошел все вагоны. Как бывший зам. редактора районной газеты, я отлично знал в лицо всех рабкоров района. Многие из них оказались тут же. Мы договорились с ними, что и на трассе они будут такими же активными помощниками большевистской печати, как были дома. Каждый день, объезжая трассу, я посещаю своих корреспондентов, беседую с ними, собираю заказанный ранее материал, советуюсь по поводу предстоящих тем» (ГА ДНР. Ф. 4674. Оп. 1. Д. 7. Л. 96).

Рабкоры в ежедневных «кочующих полевках» кратко публиковали сообщения с фронта, в которых повествовали о подвигах жителей региона, работавших на строительстве оборонительных рубежей приднепровских степей, имена передовиков заносили на Доску почета.

Отдельного внимания заслуживают отделы сатиры и юмора, существовавшие в каждой газете, рубрики, которые вели общественные корреспонденты, записывая самые острые и злободневные частушки. «Частушки эти, - писал «Донбасский отпор», - пользуются огромной популярностью, распеваются в часы отдыха и во время работы на всех дистанциях» (Донецкая область, 1982: 132).

После оккупации территории Донбасса в октябре 1941 г. нацисты стали издавать свою газету под названием «Донецкий вестник», где пропагандировались антигуманные националистические идеи с целью разжечь этническую вражду между украинцами и русскими, внести раздор в дружную семью народов СССР, освещались условия нацистского «нового порядка», результаты кампании принудительного изъятия у местного населения продовольствия и личного имущества. На страницах этого издания публиковались прежде всего правила поведения для местных жителей региона, согласно которым населению «положено быть законопослушным, не проявлять никакого свободомыслия, зарегистрироваться на бирже труда, работать в пользу “великой Германии”». Под угрозой смертной казни запрещалось предоставлять кому-либо убежище без разрешения оккупационных властей (Рендо, 1993: 51).

В каждом номере газеты «Донецкий вестник» выходили статьи, в которых нацисты пытались убедить местное население в своей доброй миссии, в благородстве немецких войск. Так, в статье «На пороге новой жизни» от 15 ноября 1941 г., описывалось счастливое будущее украинского народа: «В истории Донбасса открывается новая светлая страница. Народ выходит на широкую дорогу творческой жизни. Но это право он должен завоевать упорным повседневным трудом» (Присяжний, 2000: 118).

Жители районного центра Яма и окрестных сел 13 июня 1942 г. получили газету «За Родину», которую выпустил подпольный райком партии. Редактором этой газеты 
был коммунист Н.А. Шило, активными общественными корреспондентами и распространителями - подпольщики и партизаны Ямского отряда И.Д. Клименко, А.Ф. Шишацкий, Ю.Ф. Шишацкий, Е.И. Иванов, Б.М. Дейнега, И.М. Басистый, И.М. Храпко, B.М. Мозговой и другие. Из источников стало известно, что данную газету печатали эти патриоты самостоятельно, тайно доставляя ее в город и окрестные села, подбрасывая ее даже на стол фашистскому бургомистру и начальнику полиции (Дашичев, 1973: 328).

В газете «За Родину» жителям региона, временно попавшим под фашистскую оккупацию, рассказывалась правда об обстановке на остальной территории Советского Союза, о героических боях Красной армии на фронтах, с призывом к трудящимся Донбасса: «Дорогие братья и сестры, проживающие на временно оккупированной территории, идите в партизанские отряды, помогайте партизанам громить врага в тылу». В отдельных номерах этой партизанской газеты статьи посвящались молодежи, женщинам, военнопленным, содержали призыв к саботажу распоряжений фашистских властей, созданию захватчикам невыносимых условий на донецкой земле, а также обращения к местному населению препятствовать вывозке хлеба, скота и прочего продовольствия в Германию (Титаренко, 2009: 26).

В статье «Школа мракобесия» газеты «За Родину» от 18 сентября 1942 г. сообщалось: «В номере 41 “Донецкого вестника" на днях была напечатана речь шефа немецкого отдела пропаганды гауптмана Папенброка об основных принципах обучения и воспитания детей в школах "Великой Германии". Когда и где выступал с этой, с позволения сказать, речью Папенброк, газета умалчивает, но плешивый оратор, не успев рассказать о своих новых “принципах" воспитания детей, принял суровую позу и с угрозой сказал, что их должен усвоить каждый, если хочет понять современную войну. Так пусть же помнит он и ему подобные, что угрозами советский народ не запугаешь. Никогда дети советские не будут послушно принимать программу мракобесия, сфабрикованную шайкой бандитов, которые величают себя во временно оккупированных районах представителями высшей арийской культуры» (Титаренко, 2009: 29). Данная статья является подтверждением достойного ответа на пропаганду фашистского режима на оккупированных территориях. Такие смелые выступления в подпольной газете, издававшиеся на территории Донбасса в 1941-1943 гг., призваны были поднимать боевой дух местного населения, укреплять в них веру в Великую Победу.

В общей сложности за 7 месяцев работы в тылу врага редакция выпустила 33 номера газеты «За Родину» общим тиражом более 10 тысяч экземпляров. Благодаря сотням местных патриотов, которые, нередко рискуя собственной жизнью, поддерживали газету морально и материально, оберегая ее от нацистского контроля, удавалось регулярно ее издавать.

Известно, что в период оккупации Донбасса на территории края действовали 31 подпольный горком и райком партии, 27 партизанских отрядов и десятки подпольных партизанских групп. В большинстве из них существовали печатные средства массовой информации в виде газет или листовок. Так, в Горловской партийной организации, которую возглавлял Н.С. Щетинин, листовки распространяли 30 активистов-общественников (Дем’янчук, 1956:48).

Нередко подпольщики и партизаны Донбасса для того, чтобы обеспечить материальную базу печати газет и листовок, устраивались разнорабочими на предприятия. Так, подпольщик Борис Орлов из Буденовского комсомольского партизанского отряда Саввы Матекина, по заданию штаба устроился чертежником на работу в контору «Донбассэнерго», откуда он выносил бумагу, шрифты и другие необходимые материалы. Листовки издавались от имени «Общества партизан» (ГА ДНР. Ф. 4674. ОП. 1. Д. 7. Л. 20).

Однако фашистам удалось выследить и арестовать комсомольцев-подпольщиков, и 30 мая 1943 г. они были расстреляны. 31 мая на улицах Юзовки была распространена листовка, которая называлась «На смерть героев», со следующим текстом:

Не испугают нас расстрелы

Ни казни, ни зверства, ни тюрьма.

Мы будем биться до победы,

Пока не разобьем врага! (Голос Донбасса).

Известны случаи, когда местные патриоты, не имея связи с подпольем, сами писали и распространяли листовки, призывавшие местных жителей на борьбу оккупантами. 
В оккупированном Славянске жительница города Л.К. Шабалина приобрела типографский шрифт, наладила настоящую подпольную типографию, сама печатала листовки, незаметно распространяла их в толпе на базаре, подбрасывала в учреждения и в другие общественные места. «Гитлеровские бандиты, - говорилось в одной из них, - освобождают наш родной город не только от хлеба и одежды, но и от населения. Палачи расстреливают, заполняют овраги, балки в окрестностях города трупами наших советских людей...» (Алехина, 1988: 29). 25 февраля 1942 г. гестаповцы выследили и схватили патриотку.

Всего, по неполным данным, за период оккупации Донбасса партизаны и подпольщики отпечатали и распространили десятки газет и листовок общим тиражом 14715 экземпляров (Донецкая область, 1982: 236).

В сентябре 1943 г., после освобождения территории Донбасса, стала возрождаться и местная печать - заводская, стенная, во всех городах и районах. Возобновила выход и областная газета «Социалистический Донбасс». По этому поводу в одном из воспоминаний говорится: «Через два дня после освобождения Макеевки, в сентябре 1943 года, жители города остановились у вывешенной на доске по улице Ленина стенной газеты “Крокодил”. “Привет Армии-Освободительнице!” - крупными буквами было написано на картонном листе. Местное население, два года не видевшее официальной газеты, толпой стояло у доски. Следующий номер “Крокодила”, выпущенный через несколько дней, был озаглавлен боевым призывом: “Все силы - на восстановление!” (Социалистический Донбасс).

Стенная газета «Крокодил» (позже снова станет юмористической), которая была организована редакцией многотиражки «Кировец» (редактор А. Василенко) в 1939 г., стала первой газетой, вышедшей в освобожденной Макеевке. С сентября 1943 г. возобновился регулярный выпуск «Крокодила».

Восстановление массовой печати Донбасса началось со стенных газет, издававшихся общественниками. В период восстановления региона, когда в разрушенных городах и районах было затруднительно наладить работу типографий, снабдить их всем необходимым, на помощь донбассовцам пришла газета «Правда». В октябре 1943 г. на запасных путях в г. Горловке начал свою работу новый вагон-типография на колесах, работу которого осуществляли приехавшие в край представители центральной газеты «Правда». И к 26-й годовщине Великой Октябрьской социалистической революции вышел в свет первый номер «“Правды” в Донбассе». В статьях публиковался призыв к помощи фронту, а также к быстрейшему восстановлению Всесоюзной кочегарки.

\section{4. Заключение}

Таким образом, в оккупационный период на территории Донбасса был создан разветвленный пропагандистский механизм, главным элементом которого стала пресса. Инициатива основания официальных печатных органов принадлежала пропагандистским органам вермахта, военным комендатурам, штабам военных частей, которые реализовывали ее преимущественно через органы местного самоуправления. Однако основным рупором пропаганды в регионе оставались местные газеты, издаваемые подпольными и партизанскими отрядами или отдельными патриотами.

\section{Литература}

Алехина, 1988 - Алехина А.C. Советская публицистика периода Великой Отечественной войны: Дисс. ... канд. филол. наук. М., 1988. 213 с.

ГА ДНР - Государственный архив Донецкой Народной Республики.

ГА ЛНР - Государственный архив Луганской Народной Республики.

Голос Донбасса - Голос Донбасса. 1943. 9 апреля.

Дашичев, 1973 - Дашичев В.И. Банкротство стратегии германского фашизма: Исторические очерки. Документы и материалы. Т. 1. М.: Наука, 1973. 766 с.

Дем'янчук, 1956 - Дем’янчук I.Л. Партизанська преса України (1941-1944 рр.). Київ: Вид-во Київського ун-ту, 1956. 108 с.

Донецкая область, 1982 - Донецкая область в годы Великой Отечественной войны (1941-1945 гг.): Сб. докум. и материалов. Донецк: Донбасс, 1982. 310 с. 
Омельяненко, 1972 - Омельяненко И.Я. За наше правое дело // Герои подполья. О борьбе советских патриотов в тылу немецко-фашистских захватчиков в годы Великой Отечественной войны. Вып. 2. М.: Политиздат, 1972. С. 100-147.

Присяжний, 2000 - Присяжний $M$. Преса української еміграції в Німеччині (19451953). Львів: ЛНУ ім. І. Франка, 2000. 220 с.

Рендо, 1993 - Рендо C.I. Організація пропагандистської діяльності Червоної Армії у період бойових дій восени 1939 р. // Журналістика: історія і сучасність. 1993. № 5. С. 46-54.

Социалистический Донбасс - Социалистический Донбасс. 1943. 12 сентября.

Титаренко, 2002 - Титаренко Д.М. Преса Східної України періоду німецькофашистської окупації як історичне джерело (1941-1943 рр.). Автореф. дис. ... канд. ист. наук. Днепропетровск, 2002. 30 с.

Титаренко, 2009 - Титаренко Д.Н. Нацистская пропаганда в оккупированном Донбассе: цели, средства, условия деятельности // Новые страницы истории Донбасса: Сборник статей (книга 17/18). Донецк: ДонНУ, 2009. С. 21-33.

\section{References}

Alekhina, 1988 - Alekhina, A.S. (1988). Sovetskaya publitsistika perioda Velikoi Otechestvennoi voiny [Soviet journalism of the Great Patriotic War period]. Diss. ... kand. filol. nauk. M., 213 p. [in Russian]

GA DNR - Gosudarstvennyi arkhiv Donetskoi Narodnoi Respubliki [State Archive of the Donetsk People's Republic].

GA LNR - Gosudarstvennyi arkhiv Luganskoi Narodnoi Respubliki [State Archive of the Luhansk People's Republic].

Golos Donbassa - Golos Donbassa. 1943. 9 aprelya [The Voice of the Donbass. April 9, 1943]. [in Russian]

Dashichev, 1973 - Dashichev, V.I. (1973). [Bankruptcy of the strategy of German fascism: Historical essays. Documents and Materials]. Vol.1. M.: Nauka, 766 p. [in Russian]

Dem'yanchuk, 1956 - Dem'yanchuk, I.L. (1956). Partizans'ka presa Ukraïni (1941-1944 rr.) [Partisan Press of Ukraine (1941-1944)]. Kiïv: Vid-vo Kiïvs'kogo un-tu, 108 p. [in Ukrainian]

Donetskaya oblast', 1982 - Donetskaya oblast' v gody Velikoi Otechestvennoi voiny (19411945 gg.): Sb. dokum. i materialov [Donetsk region during the Great Patriotic War (1941-1945): Collection of documents and materials]. Donetsk: Donbass, 1982. 310 p. [in Russian]

Omel'yanenko, 1972 - Omel'yanenko, I.Ya. (1972). Za nashe pravoe delo [For our righteous cause]. Geroi podpol'ya. O bor'be sovetskikh patriotov v tylu nemetsko-fashistskikh zakhvatchikov $\mathrm{v}$ gody Velikoi Otechestvennoi voiny. Vyp. 2 [Heroes of the underground. About the struggle of Soviet patriots in the rear of Nazi invaders during the Great Patriotic War. Is. 2]. M.: Politizdat, pp. 100-147. [in Russian]

Prisyazhnii, 2000 - Prisyazhnii, M. (2000). Presa ukraïns'koï emigratsiï v Nimechchini (1945-1953) [Press of Ukrainian emigration in Germany (1945-1953)]. L'viv: LNU im. I. Franka, 220 p. [in Ukrainian]

Rendo, 1993 - Rendo, S.I. (1993). Organizatsiya propagandists'koï diyal'nosti Chervonoï Armiï u period boiovikh dii voseni 1939 r. [Organization of propaganda activities of the Red Army during the fighting in autumn 1939]. Zhurnalistika: istoriya i suchasnist'. 5: 46-54. [in Ukrainian]

Sotsialisticheskii Donbass - Sotsialisticheskii Donbass. 1943. 12 sentyabrya [Socialist Donbass. September 12, 1943]. [in Russian]

Titarenko, 2002 - Titarenko, D.M. (2002). Presa Skhidnoï Ukraïni periodu nimets'kofashists'koï okupatsiï yak istorichne dzherelo (1941-1943 rr.) [The press of Eastern Ukraine during the Nazi occupation as a historical source (1941-1943)]. Avtoref. dis. ... kand. ist. nauk. Dnepropetrovsk, 30 p. [in Ukrainian]

Titarenko, 2009 - Titarenko, D.N. (2009). Natsistskaya propaganda v okkupirovannom Donbasse: tseli, sredstva, usloviya deyatel'nosti [Nazi propaganda in the occupied Donbass: goals, means, conditions of activity]. Novye stranitsy istorii Donbassa: Sbornik statei (kniga 17/18) [New pages of the history of Donbass: Collection of articles (book 17/18)]. Donetsk: DonNU, pp. 21-33. [in Russian] 


\section{Пресса Донбасса в 1941-1943 гг.}

Татьяна Юрьевна Людоровская а , *

а Донецкий национальный университет

Аннотация. В статье анализируются печатные средства массовой информации, которые издавались на территории Донбасса в оккупационный период (1941-1943 гг.). Основные газеты региона - «Социалистический Донбасс», «Донецкий вестник», «Хлебороб», «Бахмутский вестник», «Донбасский отпор» - продолжали свою работу в период оккупационного режима, зачастую становясь подпольными. С сентября 1941 г. в Донбассе произошла реорганизация структуры печатных средств массовой информации, когда наряду с существующими стали появляться новые газеты. Сравнение материалов местных газет позволяет определить основную направленность и степень полноты описания событий, происходивших на территории Донбасса, выявить специфику деятельности оккупационных властей, а также искажения и неточности в предоставлении информации.

Ключевые слова: средства массовой информации, пресса, Донбасс, Великая Отечественная война, оккупационный режим, газета.

\footnotetext{
* Корреспондирующий автор

Адреса электронной почты: t.ludorov@mail.ru (Т.Ю. Людоровская)
} 